\title{
Cyclanilide Induces Lateral Branching in Apple Trees
}

\author{
Don C. Elfving ${ }^{1}$ and Dwayne B. Visser ${ }^{2}$ \\ Washington State University, Tree Fruit Research and Extension Center, \\ Wenatchee, WA 98801
}

Additional index words. plant growth regulator, bioregulator, Apogee, Promalin, benzyladenine, gibberellic acid, auxin, cytokinin, feathering, feather production, vegetative growth, shoot growth, Malus $\times$ domestica

\begin{abstract}
A new bioregulator, cyclanilide (CYC, Bayer Environmental Science, Montvale, N.J.), was tested for growth-related effects on apple trees over three years. Although treatment with CYC produced small reductions in shoot length, its principal effect was to stimulate the formation of lateral shoots on current-season's shoot growth and from spurs on older wood. CYC treatment of 'Scarletspur Delicious' apple trees in the nursery more than doubled the formation of well-developed feathers with wide crotch angles $\left(\approx 60^{\circ}\right)$ and with no effect on final tree height. CYC appeared to flatten the apples and reduce fruit size in one trial. CYC appears promising for lateral branch induction in apple, especially in the nursery. Chemical names used: 1-(2,4-dichlorophenylaminocarbonyl)-cyclopropane carboxylic acid (Cyclanilide); calcium 3-oxido-4-propionyl-5-oxo-4-propionylcyclohex3-enecarboxylate (prohexadione-Ca, Apogee); N-(phenylmethyl)-1H-purine-6-amine + gibberellins $\mathbf{A}_{4} \mathbf{A}_{7}$ (Promalin); polyoxyethylenepolypropoxypropanol, dihydroxypropane, 2-butoxyethanol (Regulaid).
\end{abstract}

The rapid development of lateral branching in apple trees favors early and increased yields (Ferree and Rhodus, 1987; Preston, 1968; Quinlan, 1978b, 1981; Quinlan and Preston, 1978; van Oosten, 1978, 1981; Wertheim, 1978). Bioregulators with cytokinin-like activity or which interact with auxin-mediated effects are capable of stimulating lateral shoot development in apple trees under both nursery and orchard conditions (Baldini et al., 1973; Basak et al., 1993; Cody et al., 1985a, 1985b; Elfving, 1984, 1985; Elfving and Forshey, 1978; Forshey, 1982; Greene and Autio, 1990; Jacyna, 1996; Johann, 1983; Koen et al., 1989; Larsen 1979; Miller, 1985; Plich and Basak, 1978; Quinlan, 1981; Quinlan and Tobutt, 1990; Unrath and Shaltout, 1985; Volz et al., 1994; Wertheim and Estabrooks, 1994; Williams and Billingsley, 1970). Although several products that alter auxin metabolism have been tested for branch induction in apple, none has become commercially significant (Cody et al., 1985b; Elfving, 1985; Elfving and Forshey, 1978; Hibbitt and Hardisty, 1979; Johann, 1983; Larsen 1979; Plich and Basak, 1978; Plich and Hegazi, 1977; Quinlan, 1978a, 1978b, 1981; Quinlan and Preston, 1973, 1978; Strydom and Honeyborne, 1980; van Oosten, 1981; Wertheim, 1978). Proprietary mixtures of 6-benzyladenine (BA) and gibberellic acid isomers $\mathrm{GA}_{4}$ and $\mathrm{GA}_{7}\left(\mathrm{GA}_{4+7}\right)$ are used commercially by some nurseries for branch induction (feathering) of apple, but these products do not produce satisfactory lateral branch development on all

Received for publication 17 Feb. 2004. Accepted for publication 21 June 2004. We wish to express appreciation to Bayer Environmental Science, the Washington Tree Fruit Research Commission and the Washington Dept. of Agriculture, Nursery Division for funds partially supporting these studies.

${ }^{1}$ Horticulturist and professor; to whom requests for reprints should be addressed; e-mail delfving@wsu.edu. ${ }^{2}$ Agricultural technician II. cultivars (Elfving, 1985; Jaumien et al., 1993; Lindhagen, 1998). Recently the bioregulator Cyclanilide (CYC, Bayer Environmental Science, Montvale, N.J.) became available for experimental evaluation as a bioregulator for apple. Initial information from Bayer suggested that CYC might show growth-inhibitory effects similar to prohexadione-calcium (P-Ca, BASF Corp., Research Triangle Park, NC), a gibberellic-acid biosynthesis inhibitor used commercially for reduction of vegetative growth in apple (Byers and Yoder, 1999; Greene, 1999; Unrath, 1999). The studies reported here were initiated to examine potential growth-inhibitory characteristics of CYC on apple trees and were continued to explore the effects of CYC on induction of bud activity in apple under orchard and nursery conditions.

\section{Materials and Methods}

Four experiments were conducted between 2000 and 2002. All trials employed randomized complete-block designs with at least 4 replications. Proprietary formulations of CYC (Bayer Environmental Science, Montvale, N.J.), BA plus $\mathrm{GA}_{4+7}$ (Promalin (PR), Valent BioSciences, Walnut Creek, Calif.), and prohexadione-Calcium (Apogee, P-Ca, BASF Corp., Research Triangle Park, N.C.) were used in the trials reported here. All bioregulator treatments were supplemented with $0.1 \% \mathrm{v} / \mathrm{v}$ Regulaid (Kalo, Inc., Overland Park, Kan.). Orchard plots were sprayed to runoff with a motorized hydraulic sprayer and handgun; the nursery trial was carried out using a Solo backpack sprayer fitted with two spray heads that applied a dilute spray to the upper half of each nursery tree. Orchard trees were either noncropping or carrying a small crop the year of treatment; no yield data were collected. The experiments are described below.

Experiment 1, 2000, Orondo, Wash. Applica- tions of CYC or P-Ca were made to single-tree plots in 6randomized blocks of 'Cameo'/'Gala'/ M.26 apple trees topworked to 'Cameo' in 1998. This trial was established because initial information suggested that CYC might show inhibitory effects on shoot elongation on apple. CYC at 25,50 , or $100 \mathrm{mg} \cdot \mathrm{L}^{-1}$ active ingredient (a.i.) was applied on 11 May when terminal shoots were 10 to $15 \mathrm{~cm}$ in length. For comparison, P$\mathrm{Ca}$ at $125 \mathrm{mg} \cdot \mathrm{L}^{-1}$ a.i. was applied three times at 3 -week intervals to single-tree plots in the same blocks (11 May (terminal shoots 10 to $15 \mathrm{~cm}$ ), 2 June (control terminal shoots about $30 \mathrm{~cm}$ ) and again on 19 June (control terminal shoots about $45 \mathrm{~cm})$ ). Control trees were unsprayed. After shoot growth was completed, one limb sample consisting of a branch section that grew in 1999 was selected on each test tree and the limb circumference was measured at its base (Forshey and Elfving, 1979). The lengths of all terminal shoots, all lateral/bourse shoots and new shoots induced on current-season's terminal shoots on this branch section were measured. The trees had not been pruned in the 1999-2000 dormant season prior to the start of the trial.

Experiment 2, 2001, Palisades, Wash. Applications of CYC were made to single-tree plots of 5-year-old 'TAC114 Fuji'/M.26 trees in 5 randomized blocks. These trees had not been pruned the winter before the trial began. The trees had a small crop in 2001 and were very vigorous. CYC at 100 or $250 \mathrm{mg} \cdot \mathrm{L}^{-1}$ a.i. was applied on 7 May (terminal shoots $12.9 \pm$ $0.3 \mathrm{~cm}$ ) and again on 31 May (control terminal shoots $36.6 \pm 1.9 \mathrm{~cm})$. Control trees were unsprayed. Two representative, newly developing terminal shoots on each test tree were flagged on 7 May and their lengths measured. The lengths of these same shoots were measured once each week thereafter until the last measurement on 10 Oct., at which time all tagged shoots had shown no extension growth for 2 weeks. A single sample limb consisting of branch sections that grew in 1999 and 2000 with their shoot growth for 2001 was selected on each test tree after shoot growth was completed. All terminal, lateral and bourse shoots that grew in 2001 and new shoots that were induced on the 2001 terminal shoots were measured and the basal limb circumference determined on each sample limb (Forshey and Elfving, 1979). In spring, 2002, return bloom was assessed by counting all blossom clusters developing on these same limb sections, which were not pruned during the 2001-02 dormant period.

Experiment 3, 2002, East Wenatchee, Wash. CYC (100 mg. $\mathrm{L}^{-1}$ a.i.), PR ( $250 \mathrm{mg} \cdot \mathrm{L}^{-1}$ a.i.) or a tank-mix of the two products at the same concentrations were applied to single-tree plots of 1-year-old 'Scarletspur Delicious'/B.118 trees in five randomized blocks on 23 May (terminal shoots $15.6 \pm 0.4 \mathrm{~cm}$ ). The trees had been headed strongly after the previous growing season; each tree produced numerous vigorous, upright to semi-upright new shoots in 2002 from near the heading cuts. Control trees were unsprayed. Following cessation of shoot growth, three vigorous, upright new shoots that developed in 2002 were selected on each test tree, the length of each of those shoots determined, and all buds on each of those shoots that had shown evidence 


\begin{tabular}{|c|c|c|c|c|c|c|c|c|}
\hline \multirow[b]{2}{*}{$\begin{array}{l}\text { CYC } \\
\text { concn } \\
\left(\mathrm{mg} \cdot \mathrm{L}^{-1}\right)^{\mathrm{z}}\end{array}$} & \multicolumn{2}{|c|}{ Terminal shoots } & \multicolumn{2}{|c|}{$\begin{array}{l}\text { Lateral shoots } \\
\text { induced on new } \\
\text { terminal shoots }\end{array}$} & \multicolumn{2}{|c|}{ Lateral shoots } & \multicolumn{2}{|c|}{ Total shoots } \\
\hline & $\begin{array}{c}\text { No. } / \mathrm{cm}^{2} \\
\text { LCSA }^{y}\end{array}$ & $\begin{array}{c}\text { Mean } \\
\text { length } \\
(\mathrm{cm})\end{array}$ & $\begin{array}{c}\text { No. } / \mathrm{cm}^{2} \\
\text { LCSA }^{\mathrm{y}}\end{array}$ & $\begin{array}{c}\text { Mean } \\
\text { length } \\
(\mathrm{cm})\end{array}$ & $\begin{array}{c}\text { No. } / \mathrm{cm}^{2} \\
\text { LCSA }^{y}\end{array}$ & $\begin{array}{c}\text { Mean } \\
\text { length } \\
(\mathrm{cm})\end{array}$ & $\begin{array}{c}\text { No. } / \mathrm{cm}^{2} \\
\text { LCSA }^{y}\end{array}$ & $\begin{array}{r}\text { Mean } \\
\text { length } \\
(\mathrm{cm})\end{array}$ \\
\hline Control & $0.4 \mathrm{a}$ & $71 \mathrm{a}$ & $0 \mathrm{~b}$ & -- & $3.0 \mathrm{~b}$ & $37 \mathrm{a}$ & $3.3 \mathrm{~b}$ & $41 \mathrm{a}$ \\
\hline P-Ca $125^{x}$ & $0.3 \mathrm{a}$ & $40 \mathrm{c}$ & $0 \mathrm{~b}$ & -- & $4.2 \mathrm{~b}$ & $16 \mathrm{~b}$ & $4.6 \mathrm{~b}$ & $17 \mathrm{c}$ \\
\hline CYC 25 & $0.4 \mathrm{a}$ & $55 \mathrm{~b}$ & $0 \mathrm{~b}$ & -- & $4.2 \mathrm{~b}$ & $29 a b$ & $4.6 \mathrm{~b}$ & $31 \mathrm{~b}$ \\
\hline CYC 50 & $0.3 \mathrm{a}$ & $69 a b$ & $0.2 \mathrm{~b}$ & $7 \mathrm{~b}$ & $5.9 \mathrm{a}$ & $30 \mathrm{ab}$ & $6.4 \mathrm{a}$ & $30 \mathrm{~b}$ \\
\hline CYC 100 & $0.3 \mathrm{a}$ & $81 \mathrm{a}$ & $0.7 \mathrm{a}$ & $14 \mathrm{a}$ & $6.4 \mathrm{a}$ & $27 \mathrm{ab}$ & $7.4 \mathrm{a}$ & $27 \mathrm{~b}$ \\
\hline
\end{tabular}

${ }^{\mathrm{z}}$ Mean separation in columns by Waller-Duncan Bayesian $\mathrm{k}$ ratio test following significant $\mathrm{F}$ test $(P \leq 0.05)$.

${ }^{y}$ LCSA = limb cross-sectional area, $\mathrm{cm}^{2}$.

${ }^{x}$ Three applications at 3-week intervals.

Table 2. Effects of CYC on shoot development and return bloom in 5-year-old 'TAC114 Fuji'/M.26 apple trees (Expt. 2).

\begin{tabular}{|c|c|c|c|c|c|c|c|c|c|}
\hline \multirow[b]{2}{*}{$\begin{array}{l}\text { CYC } \\
\text { concn } \\
\left(\mathrm{mg} \cdot \mathrm{L}^{-1}\right)^{2}\end{array}$} & \multicolumn{2}{|c|}{ Terminal shoots } & \multicolumn{2}{|c|}{$\begin{array}{l}\text { Lateral shoots } \\
\text { induced on new } \\
\text { terminal shoots }\end{array}$} & \multicolumn{2}{|c|}{ Lateral shoots } & \multicolumn{2}{|c|}{ Total shoots } & \multirow[b]{2}{*}{$\begin{array}{l}\text { Return bloom } 2002 \\
\text { (clusters } / \mathrm{cm}^{2} \text { LCSA }^{\mathrm{y}} \text { ) }\end{array}$} \\
\hline & $\begin{array}{l}\text { No./cm }{ }^{2} \\
\text { LCSA }^{y}\end{array}$ & $\begin{array}{l}\text { Mean } \\
\text { length } \\
(\mathrm{cm})\end{array}$ & $\begin{array}{l}\text { No./cm }{ }^{2} \\
\text { LCSA }^{y}\end{array}$ & $\begin{array}{l}\text { Mean } \\
\text { length } \\
(\mathrm{cm})\end{array}$ & $\begin{array}{l}\text { No./cm }{ }^{2} \\
\text { LCSA }^{y}\end{array}$ & $\begin{array}{l}\text { Mean } \\
\text { length } \\
(\mathrm{cm})\end{array}$ & $\begin{array}{l}\text { No./cm }{ }^{2} \\
\text { LCSA }^{y}\end{array}$ & $\begin{array}{l}\text { Mean } \\
\text { length } \\
(\mathrm{cm})\end{array}$ & \\
\hline 0 & 0.4 & 61 & 0.1 & 30 & 4.2 & 30 & 4.6 & 33 & 4.0 \\
\hline 100 & 0.4 & 40 & 1.1 & 15 & 11.2 & 21 & 11.6 & 21 & 1.1 \\
\hline 250 & 0.7 & 38 & 2.0 & 10 & 14.2 & 19 & 14.9 & 20 & 0.9 \\
\hline CYC quadratic & NS & NS & NS & NS & NS & NS & NS & NS & NS \\
\hline
\end{tabular}

${ }^{2}$ Two applications, 7 and 31 May 2001.

${ }^{y}$ LCSA = limb cross-sectional area, $\mathrm{cm}^{2}$.

NS,********Nonsignificant or significant analysis of regression at $P \leq 0.05,0.01$, or 0.001 , respectively.

of any growth activity were counted. If a bud produced a shoot, the length of that new shoot was also measured. In Spring 2003, all blossom clusters on each tree were counted and the trunk circumference was measured approximately 30 $\mathrm{cm}$ above the soil surface.

Experiment 4, 2002, Quincy, Wash. CYC (50 or $100 \mathrm{mg} \cdot \mathrm{L}^{-1}$ a.i.) with or without PR $\left(250 \mathrm{mg} \cdot \mathrm{L}^{-1}\right.$ a.i.) as a tank-mix was applied to 15-tree plots of nursery trees of 'Scarletspur Delicious'/M.7 apple trees in 4 randomized blocks on 5 July, when the tips of the newly developing scion shoots were about $90 \mathrm{~cm}$ above the soil surface. Control trees were unsprayed and another set of trees in each block was treated with PR ( $250 \mathrm{mg} \cdot \mathrm{L}^{-1}$ a.i.) only. The trees were removed from the nursery in November, 2002, bundled by replicate and stored for further evaluation. Three representative trees were selected from each replicate for detailed growth measurements, which included 1) length of the leader shoot from the bud union to the tip; 2) the height from the bud union to the first lateral branch (feather); 3 ) the number of feathers per tree (minimum length of a feather defined as 10 $\mathrm{cm})$; 4) the length of each feather; and 5) the crotch angle of each feather.

Analyses of variance or of regression were used to assess the significance of treatments and, in the appropriate trials, the relation of response to bioregulator concentration. Mean values were separated where appropriate with analysis of variance or the Waller-Duncan Bayesian k ratio test $(P \leq 0.05)$. Analyses of regression assessed the presence of significant linear and curvilinear effects of bioregulator concentrations (Elfving, 1990; Snedecor and Cochran, 1980). Statistical analyses were performed using the General Linear Models proce- dure of the Statistical Analysis System program package (SAS Institute, Cary, N.C.).

\section{Results}

Experiment 1. The number of terminal shoots per square centimeter limb cross-sectional area (LCSA) was unaffected by any treatment, but mean length was reduced by $\mathrm{P}-\mathrm{Ca}$ and by $\mathrm{CYC}$

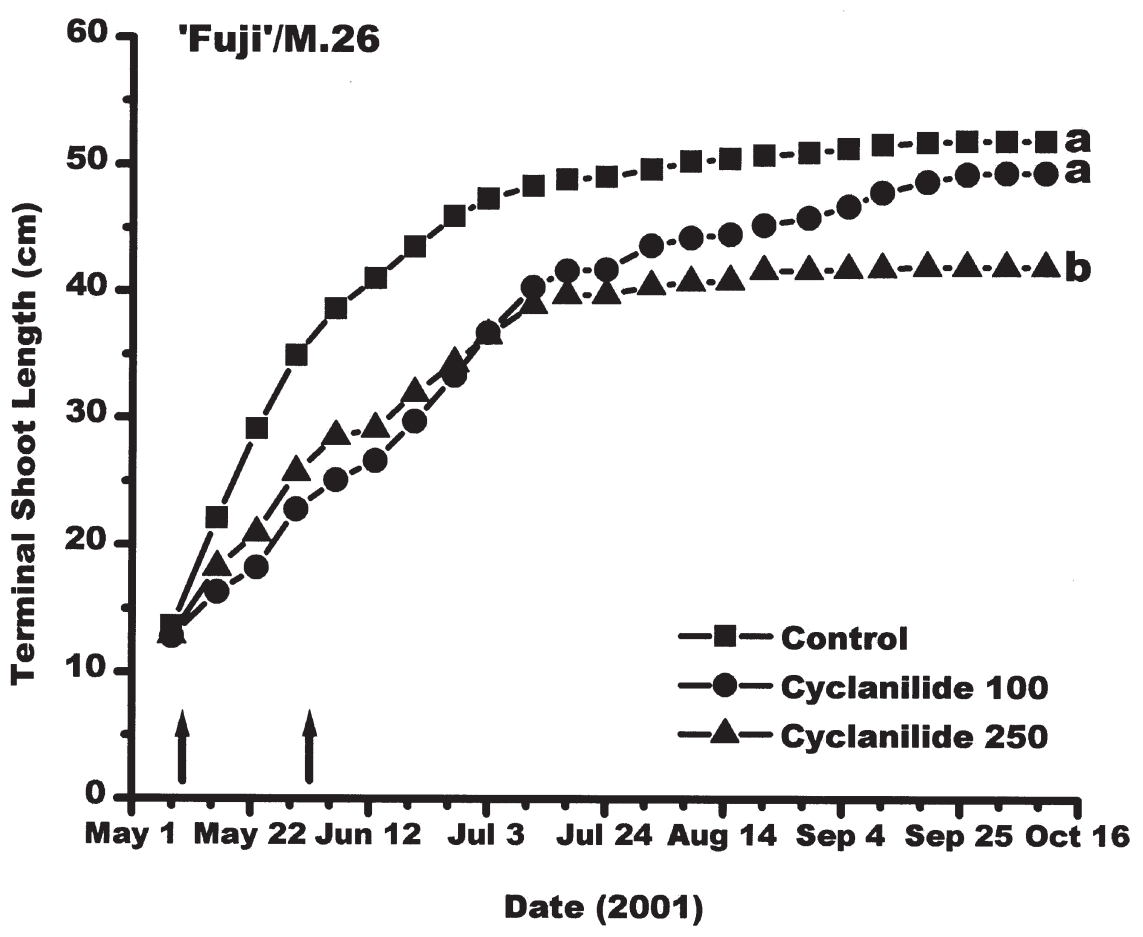

Fig. 1. Effects of CYC applied 7 May and again on 31 May on seasonal terminal extension shoot elongation in 'TAC 114 Fuji'/M.26 apple trees (Expt. 2). Arrows indicate dates of CYC application. Final shoot length means separated by Waller-Duncan Bayesian k ratio test following significant $\mathrm{F}$ test $(P \leq 0.05)$. 
Table 3. Effects of CYC and/or PR on stimulation of growth activity from buds on new shoots of 1-yearold 'Scarletspur Delicious'/B.118 apple trees (Expt. 3).

\begin{tabular}{|c|c|c|c|c|}
\hline \multirow{2}{*}{$\begin{array}{l}\text { Treatment } \\
\left(\mathrm{mg} \cdot \mathrm{L}^{-1}\right)^{\mathrm{z}}\end{array}$} & \multicolumn{3}{|c|}{ No./100 cm shoot length (2002) } & \multirow{2}{*}{$\begin{array}{l}\text { Return bloom } 2003 \\
\text { (clusters } / \mathrm{cm}^{2} \mathrm{TCSA}^{\mathrm{y}} \text { ) }\end{array}$} \\
\hline & Spurs & Shoots & Total active buds & \\
\hline Control & $0.3 \mathrm{~b}$ & $0.0 \mathrm{~b}$ & $0.3 \mathrm{c}$ & $9.7 \mathrm{a}$ \\
\hline CYC 100 & $10.6 \mathrm{a}$ & $1.0 \mathrm{ab}$ & $11.6 \mathrm{a}$ & $3.6 \mathrm{~b}$ \\
\hline PR 250 & $8.3 \mathrm{a}$ & $2.1 \mathrm{a}$ & $10.4 \mathrm{a}$ & $6.3 \mathrm{ab}$ \\
\hline CYC $100+$ PR 250 & $2.3 \mathrm{~b}$ & $1.4 \mathrm{a}$ & $3.7 \mathrm{~b}$ & $6.2 \mathrm{ab}$ \\
\hline
\end{tabular}

${ }^{\mathrm{z}}$ Mean separation by Waller-Duncan Bayesian $\mathrm{k}$ ratio test following significant $\mathrm{F}$ test $(P \leq 0.05)$. Interaction between CYC and PR significant for all data variables shown.

yTCSA $=$ trunk cross-sectional area $\left(\mathrm{cm}^{2}\right)$.

Table 4. Effects of CYC and/or PR on lateral branch (feather) development in 'Scarletspur Delicious'/M.7 apple trees in the nursery (Expt. 4).

\begin{tabular}{|c|c|c|c|c|c|c|}
\hline \multirow{2}{*}{$\begin{array}{l}\text { CYC } \\
\text { conch } \\
\left(\mathrm{mg} \cdot \mathrm{L}^{-1}\right)\end{array}$} & \multirow{2}{*}{$\begin{array}{c}\text { Central } \\
\text { leader } \\
\text { length } \\
(\mathrm{cm})\end{array}$} & \multirow{2}{*}{$\begin{array}{c}\text { Ht to } \\
\text { lowest } \\
\text { feather }(\mathrm{cm})\end{array}$} & \multirow{2}{*}{$\begin{array}{c}\text { Feathers/ } \\
\text { tree } \\
\text { (no.) }\end{array}$} & \multirow{2}{*}{$\begin{array}{l}\text { Length/ } \\
\text { feather } \\
(\mathrm{cm})\end{array}$} & \multicolumn{2}{|c|}{$\begin{array}{l}\text { Feather } \\
\text { crotch } \\
\text { angle }\left(^{\circ}\right)\end{array}$} \\
\hline & & & & & $-\mathrm{PR}$ & $+\mathrm{PR}$ \\
\hline 0 & 141 & 43 & 2.4 & 54 & 60 & 67 \\
\hline 50 & 145 & 39 & 5.1 & 40 & 63 & 65 \\
\hline 100 & 142 & 38 & 6.4 & 39 & 65 & 67 \\
\hline \multicolumn{7}{|l|}{ Significance } \\
\hline CYC linear & NS & NS & $* *$ & $* *$ & NS & NS \\
\hline CYC quadratic & NS & NS & NS & $*$ & NS & NS \\
\hline \multicolumn{7}{|l|}{$\mathrm{PR}$ concentration $\left(\mathrm{mg} \cdot \mathrm{L}^{-1}\right)^{\mathrm{z}}$} \\
\hline 0 & $141 \mathrm{a}$ & $40 \mathrm{a}$ & $4.5 \mathrm{a}$ & $47 \mathrm{a}$ & $63 \mathrm{~b}$ & --- \\
\hline 250 & $144 \mathrm{a}$ & $40 \mathrm{a}$ & $4.7 \mathrm{a}$ & $42 \mathrm{a}$ & --- & $66 \mathrm{a}$ \\
\hline
\end{tabular}

${ }^{\mathrm{z}}$ Mean separation by single-df comparison $(P \leq 0.05)$.

NS,*,**Nonsignificant or significant analysis of regression at $P \leq 0.05$ or 0.01 , respectively.
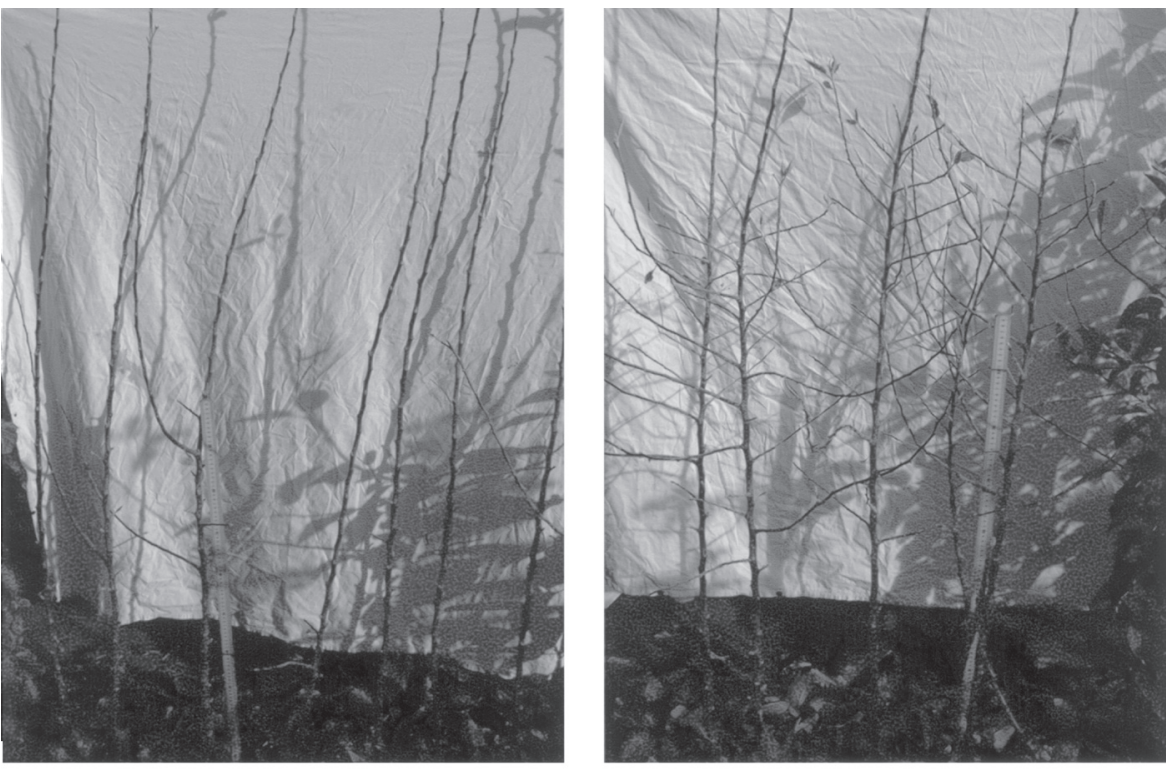

Control

Cyclanilide 100

\section{'Scarletspur Delicious'/M.7}

Fig. 2. Feathering response to treatment with CYC (100 mg. $\mathrm{L}^{-1}$ a.i.) in 'Scarletspur Delicious'/M.7 apple trees in the nursery (Expt. 4).

effect on their mean length. In contrast, P-Ca, as expected, had no effect on numbers of lateral shoots but reduced overall mean length of those shoots. The results for total shoots reflected the contribution of effects of each treatment on terminal, secondary lateral and lateral shoot development.

Experiment 2. The number of new terminal shoots was uninfluenced by CYC treatment but their mean length decreased in linear proportion to CYC concentration (Table 2). The number of new secondary shoots induced on 2001 termi-
Weekly terminal shoot length data showed that CYC treatment reduced terminal shoot elongation rate for about 11 weeks following the last application of CYC (Fig. 1). Terminal shoots treated twice with $100 \mathrm{mg} \cdot \mathrm{L}^{-1}$ a.i. continued to elongate slowly into the fall, eventually achieving a similar mean length to the sample of untreated control shoots. In contrast, shoots treated twice with $250 \mathrm{mg} \cdot \mathrm{L}^{-1}$ a.i. remained shorter in length after shoot extension ceased.

Experiment 3. Lateral shoot induction is difficult in this strain of 'Delicious'. Although CYC induced a substantial increase in total bud activity on new shoots in 2002, few of those buds formed shoots (Table 3). PR appeared to be about as effective as CYC for stimulating bud activity as either spurs or shoots. When the two products were applied together, total bud activity was reduced compared to either product applied alone. There was no effect of any treatment on the final length of the new shoots on which lateral bud activity was induced by treatments (data not shown). CYC reduced return bloom on these trees, but PR, either alone or together with CYC, had no effect on return bloom.

Experiment 4 . Treatment of nursery trees of the difficult-to-feather 'Scarletspur Delicious' with CYC and/or PR had no effect on the final length of the central leader shoot or on the height from the bud union to the first feather (Table 4). Although there was a small amount of naturally-occurring lateral branch development, treatment with CYC significantly improved feather development in direct proportion to CYC concentration (Fig. 2). At the concentration used, PR did not appear to have a beneficial effect on lateral branching. While mean feather length was reduced by CYC, the feathers produced were of acceptable length. The crotch angles of induced feathers were acceptable and unaffected by CYC treatment, but there was a small increase in crotch angle when PR was included in the treatment.

\section{Discussion}

Few apple cultivars produce a well-feathered canopy in the nursery without some treatment by the producer (Larsen, 1979, Miller 1988). Proprietary mixtures of 6-benzyladenine and gibberellic acid isomers $\mathrm{GA}_{4}$ and $\mathrm{GA}_{7}$ are registered for stimulation of feathering in apple but are not widely used in apple nursery-tree production in the western U.S. While CYC may produce some small reductions in shoot elongation in apple trees, its principal effect is to permit buds under the control of apical dominance to develop into spurs or shoots. Combining CYC with PR produced no synergistic effect or reduced induction of bud activity in one trial. The capacity to produce significant numbers of well-developed feathers with good crotch angles suggests that CYC might represent a useful product for the nursery production of feathered apple trees for high-density plantings.

CYC displays a significant additional advantage for nursery tree production because it does not produce long-term reduction of or 
deformation of growth of the terminal meristem even though it temporarily interrupts apical dominance. The development of an equivalent central leader in height after treatment is a critical feature of any branch-induction product for use in the nursery, where a strong central axis carrying several well-developed lateral shoots is the desired tree structure. Numerous chemical-pinching agents have been evaluated for stimulation of lateral branching of apple in the nursery but have not become commercially important in part because they tend to damage the shoot tip, thereby destroying that preferred tree structure (Cody et al., 1985a, 1985b; Elfving, 1985; Elfving and Forshey, 1978; Hibbitt and Hardisty, 1979; Johann, 1983; Larsen 1979; Plich and Basak, 1978; Plich and Hegazi, 1977; Quinlan, 1978a, 1978b, 1981; Quinlan and Preston, 1973, 1978; Strydom and Honeyborne, 1980; van Oosten, 1981; Wertheim, 1978).

Observations in 2001 indicated that applications of CYC to 'Fuji' trees resulted in undesirable effects on the small crop produced that year. Although no crop data were taken, fruit on treated trees appeared to develop in clusters, were of unacceptable size, appeared to be flattened in shape and were not harvested.

The interaction of endogenous cytokinins and auxins is thought to play a major role in apical dominance, the control of lateral-bud activity imposed by the actively growing shoot tip and leaves (Sachs and Thimann, 1967; Wickson and Thimann, 1958). Whether CYC interacts with naturally-occurring cytokinins, auxins or both systems to induce lateral branching is unknown. The data presented here suggest that $\mathrm{CYC}$ has considerable potential as a branching agent for apple, especially under nursery conditions.

\section{Literature Cited}

Baldini, E., S. Sansavini, and A. Zocca. 1973. Induction of feathers by growth regulators on maiden trees of apple and pear. J. Hort. Sci. 48:327-337.

Basak, A., T. Buban, and P. Kolodziejczak. 1993. Paturyl 10 WSC as a branching agent for young apple trees in nursery and orchards. Acta Hort. 329:201-203.

Byers, R.E. and K.S. Yoder. 1999. Prohexadionecalcium inhibits apple, but not peach, tree growth, but has little influence on apple fruit thinning or quality. HortScience 34:1205-1209.

Cody, C.A., F.E. Larsen, and R. Fritts, Jr. 1985a. Stimulation of lateral branch development in tree fruit nursery stock with $\mathrm{GA}_{4+7}+\mathrm{BA}$. HortScience 20:758-759.

Cody, C.A., F.E. Larsen, and R. Fritts, Jr. 1985b. Induction of lateral branches in tree fruit nursery stock with propyl-3-t-butylphenoxy acetate (M\&B 25-105). Scientia Hort. 26:111-118.

Elfving, D.C. 1984. Factors affecting apple tree re- sponse to chemical branch-induction treatments. J. Amer. Soc. Hort. Sci. 109:476-481.

Elfving, D.C. 1985. Comparison of cytokinin and apical-dominance-inhibiting growth regulators for lateral-branch induction in nursery and orchard apple trees. J. Hort. Sci. 60:447-454.

Elfving, D.C. 1990. Growth and productivity of 'Empire' apple trees following a single heading-back pruning treatment. HortScience 25:908-910.

Elfving, D.C. and C.G. Forshey. 1978. Alteration of young apple tree structure with 2,3-dihydro5,6-diphenyl-1,4-oxathiin (UBI-P-293). Acta Hort. 80:55-58.

Ferree, D.C. and W.T. Rhodus. 1987. Early performance and economic value of feathered apple trees on semi-standard rootstocks. J. Amer. Soc. Hort. Sci. 112:906-909.

Forshey, C.G. 1982. Branching responses of young apple trees to applications of 6-benzylamino purine and gibberellin $\mathrm{A}_{4+7}$. J. Amer. Soc. Hort. Sci. 107:538-541.

Forshey, C.G. and D.C. Elfving. 1979. Branch samples for yield and fruit size comparisons in apple. HortScience 14:143-144.

Greene, D.W. 1999. Tree growth management and fruit quality of apple trees treated with prohexadione-calcium (BAS 125). HortScience 34:1209-1212.

Greene, D.W. and W.R. Autio. 1990. Vegetative responses of apple trees following benzyladenine and growth regulator sprays. J. Amer. Soc. Hort. Sci. 115:400-404

Hibbitt, C.J. and J.A. Hardisty. 1979. Investigations into the use of a new plant growth regulator 'M \& B 25-105' in apple and pear tree production. Med. Fac. Landbouww. Rijksuniv. Gent 44/2:835-841.

Jacyna, T. 1996. Induction of lateral branching in nursery pear and apple trees with plant growth regulators. Fruit Var. J. 50:151-156.

Jaumien, F., B. Czarnecki, T. Mitrut, and W. Poniedziazek. 1993. Very similar effects of a mixture of $\mathrm{GA}_{3}$ and BA (6-benzyladenine) and of $\mathrm{GA}_{4+7}$ and BA on branching of some apple cultivars in nursery. Acta Hort. 329:35-42.

Johann, G. 1983. Effect of growth regulators on branching habit of some apple cultivars in the nursery. Acta Hort. 137:87-93.

Koen, T.B., K.M. Jones, and M.J. Oakford. 1989. Promoting branching in young trees of apple cv. Red Delicious using growth regulators. J. Hort. Sci. 64:521-525.

Larsen, F.E. 1979. Chemical stimulation of branching in deciduous tree fruit nursery stock with ethyl 5-(4-chlorophenyl)-2H-tetrazole-2-acetate. J. Amer. Soc. Hort. Sci. 104:770-773.

Lindhagen, M. 1998. Predicting branching in young apple trees (Malus domestica Borkh.). Acta Hort. 456:125-131.

Miller, S.S. 1985. Low-volume sprays of BA and Promalin increase branching in apple trees. HortScience 20:730-732.

Miller, S.S. 1988. Use of plant bioregulators in apple and pear culture. Hort. Rev. 10:309-401.

Plich, H and E.S. Hegazi. 1977. Induction of feathers in apple trees in the first year of growth in the nursery. Fruit Sci. Rpt. 4:11-21.

Plich, H. and A. Basak. 1978. Further trials on in- duction of feathering in young apple and cherry nursery trees. Fruit Sci. Rpt. 5:23-33.

Preston, A.P. 1968. Pruning and rootstock as factors in the production of primary branches on apple trees. J. Hort. Sci. 43:17-22.

Quinlan, J.D. 1978a. The use of growth regulators for shaping young fruit trees. Acta Hort. 80:39-48.

Quinlan, J.D. 1978b. Chemical induction of lateral branches (feathers). Acta Hort. 80:129-138.

Quinlan, J.D. 1981. New chemical approaches to the control of fruit tree form and size. Acta Hort. 120:95-106.

Quinlan, J.D. and A.P. Preston. 1973. Chemical induction of branching in nursery trees. Acta Hort. 34:123-127.

Quinlan, J.D. and A.P. Preston. 1978. The use of branching agents to replace hand pruning of young trees of Bramley's Seedling apple. J. Hort. Sci. 53:39-43.

Quinlan, J.D. and K.R. Tobutt. 1990. Manipulating fruit tree structure chemically and genetically for improved performance. HortScience 25:60-64.

Sachs, T. and K.V. Thimann. 1967. The role of auxins and cytokinins in the release of buds from dominance. Nature 201:939-940.

Snedecor, G.W. and W.G. Cochran. 1980. Statistical methods, p. 385-388. $7^{\text {th }}$ ed. Section 18.9. Iowa State Univ. Press, Ames.

Strydom, D.K. and G.E. Honeyborne. 1980. Chemically induced feathers on nursery, topworked and maiden apple and pear trees. Decid. Fruit Grower 33:412-420.

Unrath, C.R. 1999. Prohexadione-Ca: A promising chemical for controlling vegetative growth of apples. HortScience 34:1197-1200.

Unrath, C.R. and A.D. Shaltout. 1985. Branch induction on young 'Delicious' apple trees by application of growth regulators. HortScience 20:230-231.

van Oosten, H.J. 1978. Effects of initial tree quality on yield. Acta Hort. 65:123-125.

van Oosten, H.J. 1981. Effects of propyl-3-t-butyl phenoxy acetate (MB25,105) on the branching of maiden apple trees. Med. Fac. Landbouww. Rijksuniv. Gent 46/1:247-251.

Volz, R.K., H.M. Gibbs, and J. Popenoe. 1994. Branch induction on apple nursery trees: Effects of growth regulators and defoliation. N.Z. J. Crop and Hort. Sci. 22:277-283.

Wertheim, S.J. 1978. Manual and chemical induction of side-shoot formation in apple trees in the nursery. Scientia Hort. 9:337-345.

Wertheim, S.J. and E.N. Estabrooks. 1994. Effect of repeated sprays of 6-benzyladenine on the formation of sylleptic shoots in apple in the fruit-tree nursery. Scientia Hort. 60:31-39.

Wickson, M. and K.V. Thimann. 1958. The antagonism of auxin and kinetin in apical dominance. Physiol. Plant. 11:62-74.

Williams, M.W. and H.D. Billingsley. 1970. Increasing the number and crotch angles of primary branches of apple trees with cytokinins and gibberellic acid. J. Amer. Soc. Hort. Sci. 95:649-651. 